\title{
Children's Charter Rights and Convention Rights in Canada: An Advocacy Perspective
}

\author{
Kathy Vandergrift \\ Ottawa, Ontario \\ kathyvandergrift@rogers.com
}

\begin{abstract}
Realization of the human rights of children, as articulated in the Convention on the Rights of the Child, is complicated in Canada by the role of the Canadian Charter of Rights and Freedoms, the role of the Canadian Human Rights Act, and the structural division of powers between federal and provincial governments in Canada's constitution. Reflection on twenty-five years of advocacy for implementation of the Convention in Canada concludes that the current approach to implementation is inadequate to overcome the structural obstacles to full realization for Canada's children. This paper presents a case for incorporating the Convention into Canadian law; it also argues that more robust implementation of the Convention would improve the way that Canada's federal system of governance works for young people.
\end{abstract}

Key words: Children's Rights in Canada; Children and the Charter of Rights and Freedoms; Children's Rights and Federalism; 


\section{Introduction}

Canadians are proud of the Canadian Charter of Rights and Freedoms. It ranks high in surveys of national treasures and common values. One risk is an assumption that it is sufficient to protect all rights of all Canadians for all time. The rights of children, however, are not explicitly addressed in the Charter, and the limited application of the Charter to cases involving children does not provide assurance of adequate legal protection for the rights of children. In some ways, the human rights of children are the same as those of adults, but there are also significant differences that find expression in the UN Convention on the Rights of the Child. Implementation of children's rights in Canada is also complicated by other aspects of the Constitution, which emphasize the division of powers between provincial, federal, and territorial governments (FPT). Realization of many aspects of children's rights involves multiple jurisdictions. Young people and advocates increasingly express frustration that the rights of young people fall through the cracks of jurisdictional disputes between duty-bearers. Lack of legal clarity exacerbates the challenges facing policy-makers and advocates alike.

Canada enthusiastically signed the United Nations Convention on the Rights of the Child in 1990 and ratified it in 1991. Advocates hoped that the Convention would be widely used to interpret and elaborate Charter rights for children. A more robust route to implementation would be incorporation of the Convention itself into Canadian law to better protect the rights of children in Canada. Reflection on twenty-five years of advocacy for children's rights in Canada suggests that both are needed to make Canada's federal system of governance work well for children.

\section{Inadequacy of current legal protection for children's rights}

Implementation of children's rights, as articulated in the Convention on the Rights of the Child, remains a challenge in Canada. Explanatory factors include varying degrees of political will, pockets of cultural resistance to the concept of children having rights, and structural obstacles in Canada's governing systems. Twenty-five years after ratification, Canada lags behind comparable countries in domestic implementation of the Convention. At the same time, international comparisons of indicators for the well-being of children illustrate that Canada's children would benefit from improvement in implementation of Convention rights across Canada (UNICEF, 2013). 
The standard position of the federal government has been that implementation through policies and programs is adequate without making the Convention part of Canadian law. At times the rationale given for this position is that the Charter of Rights and Freedoms and the Canada Human Rights Act are adequate; making the Convention part of Canadian law is not necessary. At other times, the rationale is that incorporating the Convention into Canadian law would require so many changes in current laws that it is not feasible. Both of these views cannot be true.

The inadequacy of the current approach shows up in the periodic reviews of implementation of the Convention in Canada by the UN Committee on the Rights of the Child. Lack of progress in implementation is evident in the high number of repeated recommendations in each of the three official reviews. The Concluding Observations from the most recent $3^{\text {rd }} / 4^{\text {th }}$ review in 2012 used much stronger language in the recommendation for legal reform:

\section{The Committee recommends that the State Party finds the appropriate} constitutional path that will allow it to have in the whole territory of the State Party, including its provinces and territories, a comprehensive legal framework which fully incorporates the provisions of the Convention and its Optional Protocols and provides clear guidelines for their consistent application. (United Nations Committee on the Rights of the Child, 2012)

The UN Committee's assessment reinforces the findings of a three-year study by the Senate Human Rights Committee which found that the lack of enabling legislation contributed to the weak implementation of children's Convention rights in Canada (Standing Senate Committee on Human Rights, 2007).

With regard to jurisdictional issues, governments continue to argue that coordination mechanisms are adequate to facilitate implementation across jurisdictional boundaries. Over the years, there have been many narrowly focused FPT taskforces or working groups on emerging issues related to young people such as trafficking, electronic bullying, and restorative justice. Public reporting on outcomes is almost non-existent and there is limited evidence of sustainable impact for the amount of tax-funded resources spent on professional salaries, time, and travel. 
Most importantly, young people themselves are left out of these processes that are supposed to improve realization of their rights.

When Canada reports to the UN Committee on the Rights of the Child, it claims that the Coordinating Committee of Federal and Provincial Officials for Human Rights (CCOHR) is an effective coordinating mechanism to ensure implementation by all governing bodies in Canada's federal system of governance. The gap between these claims and actual practice in Canada contributes to the weak implementation of children's rights. Composed of appointed officials from FPT governments, the CCOHR functions as a clerical body to compile reports to UN bodies and convey concluding observations to their respective governments. It has neither the authority nor the capacity to coordinate implementation in programs and policies that impact the daily lives of children as called for in the Convention.

A review of the origins of the CCOHR helps to explain its limitations and the need for reform. It was formed at the first federal/provincial ministerial level conference on human rights held on December 11 and 12, 1975. The presenting question was whether Canada as a federal state could ratify the two umbrella international human rights conventions: the International Covenant on Economic, Social and Cultural Rights and the International Covenant on Civil and Political Rights. Discussion focused on preserving the division of powers in Canada's Constitution more than on effective implementation of human rights. The outcome was a minimalist approach that would allow ratification without ceding any powers. It included the mandate for the CCOHR as a consultative mechanism and specifically stated that "it does not make commitments for any government" (Federal-Provincial Conference on Human Rights, 1975).

For rights-holders, such as young people, the current system lacks credibility as well as effectiveness. Most rights-holders in Canada have no knowledge of the CCOHR or its work, which mostly happens behind closed doors with no public records. Only recently has it agreed to even meet briefly with human rights groups. The meetings are an opportunity to inform the officials of the concerns of civil society groups; the outcome is that officials are better prepared to defend the government when the same concerns are raised by civil society groups in UN reviews of human rights. As noted above, the lack of progress in real-life implementation is evident in the large number of repeated issues and repeated recommendations in the discourse over three official reviews and twenty-five years of implementation. 
Persistent calls for more effective implementation mechanisms for all human rights have been made by civil society organizations and parliamentary committees. Forty-eight civil society organizations joined forces in a call for substantive reform in 2008 and 2012, during the Universal Periodic Review of Canada by the UN Human Rights Council. They argued that an effective system would meet the criteria of regular public reporting and transparency, on-going engagement with rights-holders and civil society organizations, public response to official reviews, and a mandate to investigate and resolve complaints (NGO Coalition, 2008,2012). Human rights committees of both the Senate and the House of Commons have also issued study reports that conclude the CCOHR is not effective and recommend significant reform of the current monitoring and reporting system for the implementation of Canada's obligations under international human rights conventions (Standing Senate Committee on Human Rights, 2001; Standing Committee of Foreign Affairs, Sub-committee on Human Rights, 2009).

How can one explain that Canada continues to enjoy a positive reputation as an international leader in children's rights, while young people in Canada do not know about their rights and advocates find both the outcomes and the systems of governance for children woefully inadequate? News stories in Canada focus on the worst violations of children's rights in faraway countries in Africa and Asia or indigenous children on remote reserves. UNICEF Comparisons with similar countries are one-day news stories. There has not been public media exposure of the way governing bodies like the CCOHR work. Since the federal election in 2015, Global Affairs Canada has shifted its international strategy slightly to sponsor sessions on indigenous rights and women's rights at international gatherings, showcasing that Canada is addressing some of its most egregious human rights challenges such as missing indigenous women. Thus far it seems to be effective in diverting attention away from a more systematic critique of the weak systems in Canada for all areas of international human rights.

In Canada, the most compelling evidence of the need for legal reform has come in recent rulings of the Canadian Human Rights Tribunal on claims relating to indigenous child welfare and the application of Jordan's Principle (First Nations Family and Caring Society, 2016). In this case, the claimant used the anti-discrimination provisions in the Canadian Human Rights Act and the Charter of Rights to ground its case. The ruling confirmed that the rights of indigenous children to equal treatment were violated and remedies were ordered. This process took ten years of complex legal challenges and, at the time of this writing, the remedies are now being legally 
contested. This is hardly a child-friendly mechanism for protecting the rights of children. It also exposes the weaknesses of the existing review processes defended by the federal government as adequate. In the wake of this ruling, public confidence that federal officials adequately protect and report on the situation of children in Canada to the UN Committee on the Rights of the Child has eroded. Advocacy groups have recommended fundamental change in Canada to prepare for the next review in 2018, and there is growing support for the establishment of a National Commissioner for Children and Youth with a strong mandate to lead in the implementation of the Convention.

The experience with Jordan's Principle is another example of the inadequacy of current systems. The Principle seems to be a fairly simple application of Article 3 in the Convention which puts the best interests of children first: when publicly-funded services for a First Nations child are determined to be necessary, similar to those for a non-indigenous child, they will be provided without delay and decisions about whether the federal or provincial government pays will be decided later. This initiative was an attempt to resolve the jurisdictional disputes that allow the rights of children to fall through the cracks in Canada's federal system of governance. Jordan's Principle was unanimously adopted by Parliament, showing an extraordinarily high level of political will, with reasonable expectations for implementation. Ten years later, research shows weak implementation. It was then linked to the legal prohibition of discrimination under the Canadian Human Rights Act and the Charter of Rights as part of the claim by indigenous children before the Canadian Human Rights Tribunal (First Nations Family and Caring Society, 2015). The struggle for implementation continues and it is far from resolved. The lesson from this experience for advocates is that relying on non-legal mechanisms is not adequate. The rights of children need more robust grounding in law in Canada for effective implementation.

Other aspects of children's rights that are equally important under the Convention cannot even be adjudicated through the Canadian Human Rights Commission, as was done in the case of indigenous children. Before the 2012 review of children's rights in Canada, as an example, advocacy groups pursued the option of filing an official complaint about the discriminatory impact of federal policies on child care for low-income single parents. It did not fit under the existing grounds for claims of discrimination. Poverty or social conditions, one of the most significant conditions affecting child development, is not a legally recognized ground for a claim of discrimination. From an advocacy perspective, large areas of public policy that are important 
for the rights of children have no effective avenue for complaint, investigation, and correction under the current systems in Canada.

\section{Uniqueness of Children's Rights}

Some advocates promote children's rights by arguing that they are human rights for children, emphasizing common elements with the rights of adults. In the case of violence, for example, it helps to argue that children should be protected from hitting in the same way that the law prohibits hitting adults. Children should have the same freedom from violence as adults. While this seems like common sense, the long struggle to repeal section 43 of the Criminal Code, which legitimizes corporal punishment of children in limited circumstances, suggests that children have fewer rights in practice in Canada than adults.

At the same time, however, children's Convention rights highlight a number of unique elements that are not adequately addressed in human rights codes designed for adults. The importance of these provisions is another reason for incorporating the Convention into Canadian law. First, the combination of rights to protection based on vulnerability, and rights to selfdetermination are articulated in the Convention with an understanding of child development. This is unique for children and not found in domestic human rights codes designed for adults. Second, the concept of "evolving capacity" articulated in several provisions in the Convention is important for the developmental application of some aspects of human rights that children hold in common with adults. The concept of evolving capacity can be used as an interpretative principle for applying Charter rights for children; following the Convention is important to avoid processes for determining capacity that are subjective or arbitrary, depending on who is making the determination. The Convention as a whole provides a framework that reduces arbitrariness, although it cannot eliminate it totally. A third feature is the concept of the 'best interests of the child.' This concept pre-dates the Convention and is found in domestic Canadian laws such as provincial child welfare legislation. There is also a complex history of its use and abuse, as in the now-prominent case of residential schools for indigenous children which were defended as being in the best interest of children. Processes for determining the best interests of the child have varied over time. In 2007 a national conference explored its application in various areas of child development in Canada and made suggestions for improving implementation. A central conclusion was that similar to "evolving capacities," the Convention provides an essential 
framework for determining what is in the best interests of an individual child or children in general (Canadian Coalition for the Rights of Children, 2007). Fourth, the Convention combines civil, political, economic, and social rights in an integrated way that fits the context of child development. This adds value to the Charter of Rights and the Canadian Human Rights Act that treat these categories of rights in more distinct ways. Finally, the responsibilities of duty-bearers in the Convention are primarily directed toward governments, as in other human rights codes, but they also include parents and communities. The Convention more explicitly recognizes the duties of multiple actors to achieve respect and support for realizing the rights of children. This can be considered fine-tuning of general human rights principles for application in the situation of children. Its importance suggests that incorporating the Convention into Canadian law would add value to other human rights laws, such as the Charter of Rights.

\section{Convention as an Asset for the Division of Powers}

The Canadian Charter of Rights lives in some tension with other provisions in the Constitution that emphasize the division of powers between federal, provincial, and territorial governments in Canada. In practice, jurisdictional disputes complicate, or in some cases trump, rights-claims when disputes about jurisdictional responsibilities effectively deny realization of a right for a child.

When it comes to implementing Convention rights, the division of powers also plays a significant factor. The provision of many of the public services that fulfill the rights of children involve both federal and provincial governments in some way, e.g. parental leave and child care, child custody, juvenile justice. Canada's federal system of governance is often cited as a reason for the lack of progress toward fuller realization of the rights of children. While the national government leads in public accountability, provincial jurisdiction over significant areas of children's rights leads to inconsistent implementation. The current monitoring process does not systematically hold all provincial governments publicly accountable for implementing the Convention.

Turning the typical argument on its head, some advocates are now arguing that more robust implementation of the Convention could make federalism work better for young people (Canadian Coalition for the Rights of Children, 2017). Effective implementation of the Convention, which has been ratified by all provinces, could provide tools to foster co-operation 
between governing bodies. These include: the use of evidence about the real-life situations of children as the basis for policy decisions; measuring outcomes in the lives of children; listening to the voices and perspectives of young people; and using rights-based tools for assessing impact and public accountability to children as rights-bearers. It would also reduce the space for jurisdictional disputes and blaming other duty-bearers for failures to realize the rights of children. The increasing focus on sub-national governments as duty-bearers for implementing other international human rights conventions, such as the right to housing, points in the same direction. Using the Convention in this way also strengthens the role of civil society actors who play a significant role in realizing the rights of children. This is an area for further development in children's rights in Canada. It would be greatly advanced by making the Convention part of Canadian law.

\section{Summary}

From the perspective of advocacy for children's rights in Canada, the current systems are woefully inadequate to ensure good governance and realization of the rights of children. After twenty-five years, Canada lags behind comparable countries. At the same time, international comparisons of child well-being demonstrate that more robust implementation would have benefits for Canada's children.

Given the weak outcomes of intense efforts to make progress through existing channels, the reasonable course of action is to make the Convention itself part of Canadian law, to use it more consistently to interpret Charter rights for children, and to mandate its explicit use to adjudicate issues relating to children under the Canadian Human Rights Act. This step needs to accompany the promised establishment of an office of a National Commissioner for Children and Youth in order for it to be effective. While such an office could draw more attention to children's issues, its efforts will run into the same structural barriers without legal reforms that explicitly recognize the rights of children. The upcoming comprehensive $5^{\text {th }} / 6^{\text {th }}$ review of children's Convention rights in Canada, which occurs in the wake of Canada's $150^{\text {th }}$ Anniversary celebrations, is a strategic opportunity to take the first step on a path to legal reform. From an advocacy perspective it is an opportunity not to be missed. For Canada's children, it is essential to end their second-class status as citizens of Canada. 


\section{References}

Canadian Coalition for the Rights of Children (2009). Best Interests of the Child: Meaning and Application in Canada. Conference Report. http://rightsofchildren.ca/wpcontent/uploads/2016/03/BIC-Report-ENG-Web.pdf.

Canadian Coalition for the Rights of Children (2017). Children's Rights: Making Canada Work Better for Young People. A discussion paper. http://rightsofchildren.ca/wpcontent/uploads/2017/01/Childrens-Rights-Can-Make-Canada-Work-Better-for-YoungPeople.pdf.

Federal-Provincial Conference on Human Rights. Final Communique. December 11 and 12, 1975.

First Nations Child and Family Caring Society (2016). I Am A Witness; Canadian Human Rights Tribunal Hearing. Information sheets, evidence, and judgements. https://fncaringsociety.com/i-am-witness.

First Nations Child and Family Caring Society (2016). Jordan's Principle: Resolving Jurisdictional Disputes Affecting Services to First Nations Children. https://fncaringsociety.com/jordans-principle.

Government of Canada (2017). Continuing Committee of Officials and Human Rights (CCOHR); a factsheet distributed at a meeting of the CCOHR, June 7, 2017.

NGO Coalition (2012). Empty Words and Double Standards: Canada's Failure to Respect and Uphold International Human Rights: A Joint Submission to the United Nations Human Rights Council in relation to the May 2013 Universal Periodic Review of Canada October, 2012. http://www.amnesty.ca/sites/amnesty/files/upr16 ngo coalition submission for the upr _of_canada_october_2012_eng.pdf.

NGO Coalition (2008). Promise and Reality: Canada's International Human Rights Implementation Gap; Joint NGO Submission to the United Nations Human Rights Council in relation to the February 2009 Universal Periodic Review of Canada, September 9, 2008. 
http://www.socialrightscura.ca/documents/UPR/JS1_CAN_UPR_S4_2009_SocialRights AdvocacyCentre Etal JOINT.pdf.

Standing Committee on Foreign Affairs and International Development, Subcommittee on International Human Rights (2010). Canada's Universal Periodic Review and BeyondUpholding Canada's International Reputation as a Global Leader in the Field of Human Rights. Report to Parliament. November, 2010. http://publications.gc.ca/collections/collection_2010/parl/XC11-403-1-1-02-eng.pdf.

Standing Senate Committee on Human Rights. Children: The Silenced Citizens; Effective Implementation of Canada's International Obligations with Respect to the Rights of Children. Final Report. April, 2007, pp. 40-45. www.senate-senat.ca/rights-droits.asp.

Standing Senate Committee on Human Rights. Promises to Keep: Implementing Canada's Human Rights Obligations. December, 2001. https://sencanada.ca/content/sen/committee/371/huma/rep/rep02dec01-e.htm.

UNICEF Office of Research (2013). Child Well-being in Rich Countries: A comparative overview, Innocenti Report Card 11, UNICEF Office of Research, Florence.

United Nations Committee on the Rights of the Child (2012). Concluding Observations: Canada. CRC/C/CAN/CO/3-4, 5 October 2012, paragraph 11. 